\title{
Keterkaitan Karakteristik Pelajar \& Perjalanannya Terhadap Kesediaan Menggunakan Bus Sekolah di Surabaya
}

\author{
Shofia Ermirasari dan Ketut Dewi Martha Erli Handayeni \\ Departemen Perencanaan Wilayah dan Kota, Fakultas Teknik Sipil dan Perencanaan, Institut \\ Teknologi Sepuluh Nopember (ITS) \\ e-mail: erli.martha@gmail.com
}

\begin{abstract}
Abstrak - Bangkitan dan tarikan lalu lintas tata guna lahan, khususnya pada kawasan pendidikan, merupakan salah satu kegiatan yang sering menyebabkan terjadinya kemacetan lalu lintas. Penggunaan kendaraan pribadi sebagai moda menuju ke sekolah masih dominan di Kota Surabaya. Bus sekolah sebagai strategi Transport Demand Management (TDM) memberikan salah satu solusi untuk mengurangi kemacetan. Kecenderungan para pelajar menggunakan kendaraan pribadi sebagai moda menuju sekolah menunjukkan adanya faktor-faktor yang mempengaruhi pelajar dalam pemilihan moda menuju sekolah. Oleh karena itu, dibutuhkan suatu kajian yang mengidentifikasi karakteristik pelajar dan perjalanannya terhadap kesediaannya menggunakan bus sekolah di Surabaya. Metode penelitian yang digunakan adalah deskriptif kuantitatif, dengan metode analisis Crosstab. Dalam metode analisis Crosstab, karakteristik pelajar dan perjalanannya menuju sekolah akan disilangkan terhadap kesediaannya menggunakan bus sekolah, Dari hasil studi menunjukkan bahwa kesediaan menggunakan bus sekolah memiliki keterkaitan yang signifikan dengan kepemilikan kendaraan dengan nilai signifikansi sebesar 0,081 dan nilai keterkaitan sebesar 0,209 yang berarti memiliki keterkaitan yang rendah. Pemilihan bus sekolah sebagai angkutan menuju sekolah di Surabaya, besar dipengaruhi oleh penyediaan atribut pelayanan yang lebih baik dibanding angkutan pribadi.
\end{abstract}

Kata kunci-Bus Sekolah, Analisis Crosstab, Atribut Pelayanan Bus Sekolah.

\section{PENDAHULUAN}

$\mathrm{T}$ RANSPORTASI manusia atau barang biasanya bukanlah merupakan tujuan akhir, oleh karena itu permintaan akan jasa transportasi dapat disebut sebagai permintaan turunan (derived demand) yang timbul akibat adanya permintaan akan komoditi atau jasa lainnya. Dengan demikian permintaan transportasi baru akan ada apabila terdapat atribut-atribut pendorongnya. Permintaan jasa transportasi tidak berdiri sendiri, melainkan tersembunyi dibalik kepentingan yang lain [1]. Pada dasarnya permintaan angkutan diakibatkan oleh halhal berikut: kebutuhan manusia untuk berpergian dari lokasi lain dengan tujuan mengambil bagian di dalam suatu kegiatan, misalnya bekerja, berbelanja, ke sekolah, dan lain- lain; kebutuhan angkutan barang untuk dapat digunakan atau dikonsumsi di lokasi lain [2].
Menurut data Badan Pusat Statistik, jumlah kendaraan bermotor jenis mobil pada tahun 2013-2015 mengalami peningkatan sebanyak 54\% menjadi 91.043 kendaraan mobil dan jumlah kendaraan sepeda motor pada tahun 2013-2015 mengalami peningkatan sebanyak $10 \%$ menjadi 1.655 .891 kendaraan [3]. Laju tingkat konsumtif penduduk akan tersedianya kendaraan bermotor, menjadikan transportasi bertambah dari tahun ke tahun sebagai salah satu yang sangat berpengaruh dalam tingkat kemacetan [4]. Bangkitan dan tarikan lalulintas tata guna lahan, khususnya pada kawasan pendidikan, merupakan salah satu kegiatan yang sering menyebabkan terjadinya kemacetan lalu lintas. Penggunaan kendaraan pribadi sebagai moda menuju ke sekolah terhitung $88 \%$ sedangkan $12 \%$ menggunakan angkutan umum [5]. Dengan permasalahan tersebut, dibutuhkan suatu strategi untuk menanggulangi kemacetan yang diharapkan dapat mengurangi kemacetan lalu lintas di Surabaya. Transport Demand Management (TDM) merupakan suatu upaya untuk mengurangi jumlah kendaraan yang menggunakan sistem jalan dengan memberikan berbagai pilihan mobilitas bagi mereka yang ingin melakukan perjalanan [6]. Salah satu strategi TDM adalah ridesharing, yaitu salah satu moda actualive yang termasuk ke dalam kategori voluntarism (kesukarelaan), yang dimaksud kesukarelaan disini adalah tidak bersifat memaksa dan bergantung pada tingkat kesukarelaan pelaku perjalanan dalam memilih ridesharing sebagai moda transportasi [7]. Ridesharing adalah satu perjalanan berpergian bersama dengan menggunakan satu kendaraan pribadi, seperti mobil, truck penjemputan, van dan bus [8]. Bus sekolah adalah angkutan kelompok (ridesharing) yang khusus diperuntukkan bagi perjalanan para pelajar atau siswa sekolah.

Dalam hal ini, bus sekolah dapat menjadi salah satu actualive yang bisa diterapkan untuk mengubah perilaku perjalanan siswa yang tidak efisien yaitu menggunakan kendaraan pribadi dengan tingkat okupansi dan keselamatan yang rendah seperti kendaraan pribadi roda empat dan sepeda motor, sekaligus meningkatkan layanan transportasi actua bagi siswa yang tidak memiliki kendaraan pribadi [9]. Dengan pengadaan bus sekolah ini memberikan salah satu solusi untuk mengurangi kemacetan akibat meningkatnya volume kendaraan pribadi baik mobil maupun sepeda motor yang terjadi pada peak hour pagi hari saat siswa berangkat sekolah [10]. Peran strategi bus sekolah $1,9 \%$ sebagai pemecah 
pemilihan moda, maka diperkirakan akan menambah kecepatan rata-rata bus sekolah sekitar 5-10 km/jam dan pengurangan kemacetan sebesar 5,85\% [11].

Surabaya sebagai kota terbesar kedua memiliki jumlah pelajar sebanyak 522.267 jiwa dengan jumlah SMA 149 sekolah dan jumlah SMK 106 sekolah [3]. Kota Surabaya memiliki bus sekolah yang telah beroperasi sejak tahun 2004. Bus sekolah dengan melayani 3 rute menurut [12], terjadi penurunan penggunaan bus sekolah di Surabaya yang signifikan dari tahun 2010 sebanyak 25.200 penumpang hingga pada tahun 2015 menurun menjadi 12.960 penumpang atau dapat dikatakan terjadi penurunan sebanyak 12.240 penumpang. Dari studi sebelumnya siswa yang bersekolah di area Jalan Wijaya Kusuma, diketahui $57 \%$ bersedia naik bus sekolah, $12 \%$ tidak bersedia naik bus sekolah dan $31 \%$ abstan [11]. Sehingga dalam penelitian ini akan diketahui keterkaitan karakteristik pelajar dan perjalanannya terhadap kesediaannya menggunakan bus sekolah.

Bus sekolah sebagai salah satu strategi TDM dalam kategori voluntarism (sukarela), artinya keputusan pemilihan bus sekolah sebagai moda transportasi sekolah dipengaruhi oleh keputusan pelaku perjalanan. Dominasi penggunaan kendaraan pribadi sebagai moda menuju sekolah menunjukkan adanya faktor-faktor yang mempengaruhi pelajar dalam pemilihan moda menuju sekolah. Oleh karena itu, dibutuhkan suatu kajian yang mengidentifikasi karakteristik pelajar dan perjalanannya terhadap kesediaannya menggunakan bus sekolah di Surabaya.

\section{METODE PENELITIAN}

\section{A. Variabel Penelitian}

Jenis penelitian ini termasuk dalam penelitian deskriptif dengan pendekatan kuantitatif. Tujuan dari penelitian deskriptif ini adalah untuk membuat deskripsi atau gambaran mengenai preferensi pelaku perjalanan secara sistematis,

actual, dan akurat mengenai situasi atau kejadian yang kemudian diolah secara kuantitatif untuk menerangkan karakteristik pelajar dan perjalannya. Menurut Sugiyono (2009), variabel penelitian pada dasarnya adalah segala sesuatu yang berbentuk apa saja yang ditetapkan oleh peneliti untuk dipelajari sehingga diperoleh informasi tentang hal tersebut, kemudian ditarik kesimpulannya. Berikut adalah variabel yang digunakan dalam penelitian ini:

Tabel 1.

Variabel Penelitian

\begin{tabular}{llll}
\hline \hline No & Indikator & Variabel & Definisi Operasional \\
\hline 1 & Karakteristik & Kepemilikan & Memiliki atau berhak \\
& Pelaku & kendaraan & $\begin{array}{l}\text { seutuhnya untuk } \\
\text { menggunakan suatu } \\
\text { kendaraan }\end{array}$ \\
& Perjalanan & Jenis Kelamin & $\begin{array}{l}\text { Jenis kelamin yang dimiliki } \\
\text { yaitu laki-laki atau }\end{array}$ \\
& & perempuan \\
& Karakteristik & Asal-Tujuan & $\begin{array}{l}\text { Asal pelaku perjalanan } \\
\text { yaitu rumah dan tujuan }\end{array}$ \\
& Perjalanan & Perjalanan & $\begin{array}{l}\text { pelaku perjalanan yaitu } \\
\text { sekolah yang dituju } \\
\end{array}$ \\
& & Jarak fisik (kilometer) \\
& & antara asal (rumah) dan \\
& & tujuan (sekolah) \\
\hline \hline
\end{tabular}

\begin{tabular}{lll}
\hline \hline No Indikator & Variabel & Definisi Operasional \\
\hline & Waktu & Waktu keberangkatan, \\
& Perjalanan & waktu tempuh dan waktu \\
& & kepulangan pelajar \\
& menuju/dari sekolah
\end{tabular}

Sumber : Hasil analisis, 2017

\section{B. Metode Pengumpulan Data}

Dalam menentukan sampel, digunakan metode proportionate stratified random sampling (sampling acak secara proporsional dengan stratifikasi). Para pelajar jenjang menengah atas kelas 11 dan 12 yang sekolahnya terlayani oleh bus sekolah di Surabaya dengan golongan choice/pilihwan dipilih sebagai populasi karena pelajar kelas 11-12 telah berhak untuk memililiki Surat Ijin Mengemudi (SIM) dan dalam pengadaan bus sekolah tidak ada paksaan untuk menggunakannya. Jumlah sekolah jenjang menengah atas yang terlayani oleh bus sekolah terdiri dari 20 SMA dan 6 SMK dengan jumlah pelajar sebanyak 20.515 pelajar. Dari jumlah populasi tersebut, kemudian dihitung sampel yang akan diambil menggunakan rumus Slovin sebagai berikut:

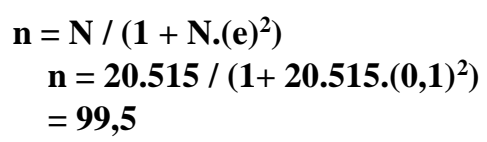

Sehingga didapati 100 sampel yang dibagi secara proporsional pada setiap strata dan sekolahnya. Metode pengumpulan data dibedakan menjadi dua, yaitu pengumpulan data sekunder dan pengumpulan data primer. Berikut adalah tabel metode pengumpulan data:

Tabel 2.

Metode Pengumpulan Data

\begin{tabular}{|c|c|c|c|}
\hline No & Data & $\begin{array}{c}\text { Teknik Pengumpulan } \\
\text { Data }\end{array}$ & Sumber \\
\hline 1 & $\begin{array}{l}\text { Karakteristik } \\
\text { pelaku } \\
\text { perjalanan }\end{array}$ & $\begin{array}{l}\text { Survei } \\
\text { (kuesioner) }\end{array}$ & Pelajar \\
\hline 2 & $\begin{array}{l}\text { Karakteristik } \\
\text { perjalanan }\end{array}$ & $\begin{array}{l}\text { Survei } \\
\text { (kuesioner) }\end{array}$ & Pelajar \\
\hline 3 & $\begin{array}{l}\text { Jumlah pelajar } \\
\text { SMA dan SMK }\end{array}$ & Survei Sekunder & $\begin{array}{l}\text { Kementrian } \\
\text { Pendidikan dan } \\
\text { Budaya }\end{array}$ \\
\hline 4 & $\begin{array}{ll}\text { Rute } & \text { dan } \\
\text { jadwal } & \\
\text { pelayanan } & \text { bus } \\
\text { sekolah } & \end{array}$ & Survei Sekunder & $\begin{array}{l}\text { Dinas } \\
\text { Perhubungan } \\
\text { Kota Surabaya }\end{array}$ \\
\hline
\end{tabular}

Sumber: Hasil analisis, 2017

\section{Metode Analisis}

Metode analisis yang digunakan dalam penelitian ini adalah metode statistik deskriptif dan analisis Crosstab. Metode statistik deskriptif digunakan untuk proses mengolah data yang telah di dapatkan dari survei kuesioner, selanjutnya dilakukan analisis Crosstab untuk mengukur pengaruh karakteristik pelajar terhadap kesediaan menggunakan bus sekolah. Analilis Crosstab dalam penelitian ini menggunakan SPSS 2.0. sebagai alat analisis. Dari hasil analisis ini dapat diketahui ada atau tidaknya hubungan antara karateristik pelajar dan perjalannya terhadap kesediaannya menggunakan bus sekolah. 


\section{HASIL DAN PEMBAHASAN}

\section{A. Mengidentifikasi Karakteristik Pelajar Dan Perjalanannya Menuju Sekolah di Surabaya}

Untuk mengidentifikasi karakteristik pelajar dan perjalannya digunakan variabel kepemilikan kendaraan, jenis kelamin, asal-tujuan perjalanan, panjang perjalanan dan waktu perjalanan. Pelajar sebagai pelaku perjalanan dan memiliki karakteristik pola pergerakan yang berbeda-beda. Dari karakteristik yang berbeda tersebut, para pelajar dibedakan menjadi dua, yaitu pelajar yang bersedia menggunakan bus sekolah apabila pelayanan bus sekolah ditingkatkan dan pelajar yang tidak bersedia menggunakan bus sekolah.

a. Identifikasi Karakteristik Pelajar

- Kepemilikan kendaraan

Berdasarkan hasil survey kuesioner, seluruh pelajar sekolah memiliki kendaraan pribadi. Berikut adalah tabel kepemilikan kendaraan pribadi berdasarkan kesediaannya menggunakan bus sekolah:

\section{Tabel 3.}

Kepemilikan Kendaraan Pribadi Berdasarkan Kesediaannya Menggunakan Bus Sekolah

\begin{tabular}{|c|c|c|c|c|}
\hline \multirow[t]{2}{*}{ No. } & \multirow{2}{*}{$\begin{array}{c}\text { Jumlah } \\
\text { Kepemilikan } \\
\text { Kendaraan } \\
\text { Pribadi }\end{array}$} & \multicolumn{2}{|c|}{$\begin{array}{c}\text { Kesediaan } \\
\text { menggunakan bus } \\
\text { sekolah }\end{array}$} & \multirow[t]{2}{*}{ Total } \\
\hline & & Bersedia & $\begin{array}{c}\text { Tidak } \\
\text { Bersedia }\end{array}$ & \\
\hline 1. & $0-2$ & 38 & 2 & 40 \\
\hline 2. & $3-5$ & 49 & 13 & 62 \\
\hline \multirow[t]{2}{*}{3.} & $6-8$ & 7 & 1 & 8 \\
\hline & Total & 94 & 16 & 110 \\
\hline
\end{tabular}

Sumber: Hasil analisis, 2017

Dari tabel dan diagram di atas dapat diketahui bahwa pelajar sekolah di Surabaya paling banyak memililki jumlah kendaraan sebanyak 3-5 unit dengan total 62 pelajar. Pelajar yang memiliki kendaraan 3-5 unit memiliki angka tertinggi yang bersedia menggunakan bus sekolah sekaligus tertinggi yang tidak bersedia menggunakan bus sekolah.

- Jenis Kelamin

Berdasarkan hasil survey kuesioner, berikut adalah tabel jenis kelamin berdasarkan kesediaannya menggunakan bus sekolah :

Tabel 4.

Jenis Kelamin Berdasarkan Kesediaannya Menggunakan Bus Sekolah

\begin{tabular}{|c|c|c|c|c|}
\hline \multirow[t]{2}{*}{ No } & \multirow[t]{2}{*}{$\begin{array}{l}\text { Jenis } \\
\text { Kelamin }\end{array}$} & \multicolumn{2}{|c|}{$\begin{array}{c}\text { Kesediaan } \\
\text { Menggunakan Bus } \\
\text { Sekolah }\end{array}$} & \multirow[t]{2}{*}{$\begin{array}{c}\text { Tota } \\
\text { I }\end{array}$} \\
\hline & & Bersedia & $\begin{array}{c}\text { Tidak } \\
\text { Bersedia }\end{array}$ & \\
\hline 1 & Laki-Laki & 39 & 9 & 48 \\
\hline \multirow[t]{2}{*}{2} & Perempuan & 55 & 7 & 62 \\
\hline & Total & 94 & 16 & 110 \\
\hline
\end{tabular}

Sumber: Hasil analisis, 2017

Dari hasil survey yang ditabulasikan pada tabel dan diagram di atas, terdapat 48 pelajar laki-laki dan 62 pelajar perempuan. Jumlah pelajar yang bersedia menggunakan bus sekolah paling tinggi adalah pelajar yang berjenis kelamin perempuan dan yang paling tinggi tidak bersedia adalah laki-laki. b. Identifikasi Karakteristik perjalanan pelajar menuju sekolah

- Asal Tujuan Perjalanan

Pola pergerakan pelajar dari rumah menuju sekolah sangat beragam. Berikut adalah gambar peta origin - destination pelajar sekolah di Surabaya:

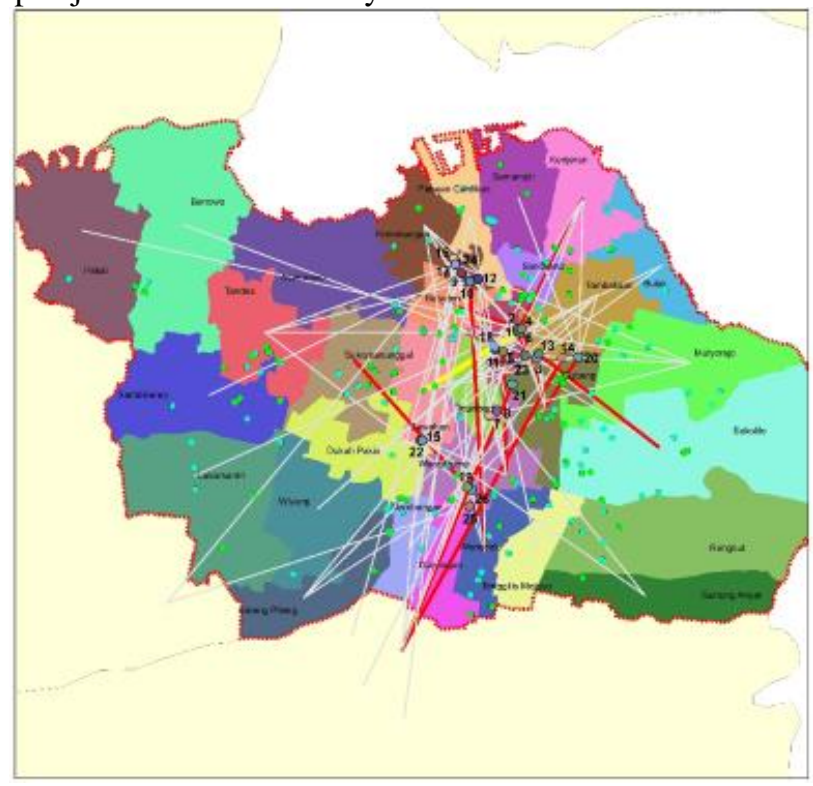

Gambar 1. Peta Origin-Destination Pelajar Sekolah di Surabaya.

Sumber: Hasil analisis, 2017.

Dari gambar tersebut, dapat dilihat bahwa distribusi yang memiliki asal tujuan yang sama adalah yang bergaris warna merah dan tebal.

- Panjang Perjalanan

Panjang perjalanan yang dimaksud dalam penelitian disini adalah jarak dari asal (rumah) menuju ke tujuan (sekolah). Berikut ialah tabel panjang perjalanan pelajar di Surabaya:

Tabel 5.

Panjang Perjalanan Berdasarkan Kesediaannya Menggunakan Bus Sekolah

\begin{tabular}{ccccc}
\hline \hline & & \multicolumn{2}{c}{$\begin{array}{c}\text { Kesediaan } \\
\text { Menggunakan Bus } \\
\text { Sekolah }\end{array}$} & Tota \\
No & $\begin{array}{c}\text { Kategori } \\
\text { Jarak } \\
\text { (kilometer) }\end{array}$ & \multicolumn{2}{c}{ l } & Tidak \\
\cline { 3 - 4 } & & Bersedia & Bersedia & \\
\hline 1 & $2-5,5$ & 28 & 4 & 32 \\
2 & $5,6-9$ & 32 & 5 & 37 \\
3 & $9,1-12,5$ & 17 & 5 & 22 \\
4 & $12,6-16$ & 8 & 2 & 10 \\
5 & $16,1-19,5$ & 1 & 0 & 1 \\
6 & $19,6-23$ & 4 & 0 & 4 \\
7 & $23,1-26,5$ & 2 & 0 & 2 \\
8 & $26,6-30$ & 2 & 0 & 2 \\
& Total & 94 & 16 & 110 \\
\hline \hline
\end{tabular}

Sumber: Hasil analisis, 2017

Panjang perjalanan pelajar sekolah di Surabaya paling jauh adalah $30 \mathrm{~km}$ dan paling pendek/dekat adalah $2 \mathrm{~km}$. Ratarata perjalanan pelajar sekolah di Surabaya adalah 5,6 km $9 \mathrm{~km}$. Dari tabulasi di atas, dapat diketahui bahwa pelajar 
yang paling banyak bersedia adalah yang memiliki panjang perjalanan $5,6-9 \mathrm{~km}$ dan yang paling banyak tidak bersedia adalah perjalanan dengan panjang $5,6-9 \mathrm{~km}$ serta 9,1-12,5 $\mathrm{km}$.

- Waktu Keberangkatan

Waktu keberangkatan pelajar di Surabaya relatif sama, yaitu paling awal pukul 05.15 WIB dan paling akhir pukul 06.25 WIB. Berikut adalah tabel waktu keberangkatan berdasarkan kesediaannya menggunakan bus sekolah:

Tabel 6.

Waktu Keberangkatan Berdasarkan Kesediaannya Menggunakan Bus Sekolah

\begin{tabular}{ccccc}
\hline \hline & & \multicolumn{2}{c}{$\begin{array}{c}\text { Kesediaan } \\
\text { Menggunakan Bus } \\
\text { Nekolah }\end{array}$} & \\
No. & $\begin{array}{c}\text { Kaktu } \\
\text { Kerangkatan } \\
\end{array}$ & \multicolumn{2}{c}{ Total } \\
\cline { 3 - 4 } & & 1 & 1 & 2 \\
\hline 1 & $05.15-05.24$ & 12 & 3 & 15 \\
2 & $05.25-05.33$ & 5 & 0 & 5 \\
3 & $05.34-05.42$ & 20 & 5 & 25 \\
4 & $05.43-05.51$ & 42 & 6 & 48 \\
5 & $05.52-06.00$ & 4 & 0 & 4 \\
6 & $06.01-06.09$ & 9 & 1 & 10 \\
7 & $06.10-06.18$ & 1 & 0 & 1 \\
8 & $06.19-06.27$ & 94 & 16 & 110 \\
\hline \hline
\end{tabular}

Sumber: Hasil analisis, 2017

Dari tabulasi waktu keberangkatan pelajar yang paling banyak bersedia dan tidak bersedia adalah yang berangkat pukul 05.52-06.00.

- Waktu Kepulangan

Waktu kepulangan pelajar sama dengan waktu kepulangan sekolahnya. Berikut adalah tabel waktu kepulangan pelajar di Surabaya:

Tabel 7.

Waktu Kepulangan Berdasarkan Kesediaannya Menggunakan Bus Sekolah

\begin{tabular}{|c|c|c|c|c|}
\hline \multirow{2}{*}{ No. } & \multirow{2}{*}{$\begin{array}{c}\text { Waktu } \\
\text { Kepulangan } \\
\text { (WIB) }\end{array}$} & \multicolumn{2}{|c|}{$\begin{array}{c}\text { Kesediaan } \\
\text { Menggunakan Bus } \\
\text { Sekolah }\end{array}$} & \multirow{2}{*}{$\begin{array}{c}\text { Tota } \\
1\end{array}$} \\
\hline & & Bersedia & $\begin{array}{c}\text { Tidak } \\
\text { Bersedia }\end{array}$ & \\
\hline 1 & $13.00-13.30$ & 8 & 1 & 9 \\
\hline 2 & $13.31-14.00$ & 16 & 2 & 18 \\
\hline 3 & $14.01-14.30$ & 0 & 0 & 0 \\
\hline 4 & $14.31-15.00$ & 25 & 5 & 30 \\
\hline 5 & $15.01-15.30$ & 37 & 7 & 44 \\
\hline 6 & $15.31-16.00$ & 5 & 1 & 6 \\
\hline 7 & $16.01-16.30$ & 0 & 0 & 0 \\
\hline \multirow[t]{2}{*}{8} & $16.31-17.00$ & 3 & 0 & 3 \\
\hline & Total & 94 & 16 & 110 \\
\hline
\end{tabular}

Sumber: Hasil analisis, 2017

Waktu kepulangan pelajar di Surabaya cukup beragam dengan waktu kepulangan paling awal adalah pukul 13.00 WIB dan waktu kepulangan paling akhir adalah pukul 17.00 WIB. Dari tabulasi waktu kepulangan pelajar yang paling banyak bersedia dan tidak bersedia adalah yang pulang pukul 15.01-15.30.

- Waktu Tempuh

Waktu tempuh yang dimaksud adalah waktu yang dihabiskan dalam perjalanan untuk menempuh tujuan. Berikut adalah waktu tempuh pelajar berdasarkan kesediaannya menggunakan bus sekolah:

Tabel 7.

Waktu Tempuh Berdasarkan Kesediaannya Menggunakan Bus Sekolah

\begin{tabular}{ccccc}
\hline \hline & & \multicolumn{3}{c}{ Kesediaan Menggunakan } \\
No. & $\begin{array}{c}\text { Waktu } \\
\text { Tempuh } \\
\text { (menit) }\end{array}$ & Bekolah & \\
\cline { 3 - 4 } & & 13 & Total \\
& $5-12$ & 22 & 3 & 16 \\
\hline 1 & $13-19$ & 30 & 2 & 24 \\
2 & $20-26$ & 16 & 4 & 34 \\
3 & $27-33$ & 9 & 4 & 20 \\
4 & $34-40$ & 3 & 2 & 11 \\
5 & $41-47$ & 0 & 0 & 3 \\
6 & $48-54$ & 1 & 0 & 0 \\
7 & $55-60$ & 94 & 16 & 2 \\
8 & Total & & & 110 \\
\hline \hline
\end{tabular}

Sumber: Hasil analisis, 2017

Waktu tempuh perjalanan pelajar untuk mencapai sekolahnya paling cepat adalah 5 menit hingga paling lama adalah 60 menit. Dari tabulasi di atas, yang paling banyak bersedia menggunakan bus sekolah adalah pelajar dengan waktu tempuh 13-19 menit dan yang paling banyak tidak bersedia menggunakan bus sekolah adalah yang memiliki waktu tempuh 20-26 menit dan 27-33 menit.

B. Analisis keterkaitan antara karakteristik pelajar dan perjalanannya dengan kesediaan menggunakan bus sekolah

Karakteristik pelajar dan perjalannya memiliki beberapa variabel diantaranya yaitu kepemilikan kendaraan, jenis kelamin, panjang perjalanan, waktu keberangkatan, waktu kepulangan dan waktu tempuh. Berdasarkan hasil survey karakteristik pelajar dan perjalanannya menuju sekolah di Surabaya, terdapat perbedaan karakteristik pelajar. Dari perbedaan karakteristik tersebut, dapat diketahui variabel yang berpengaruh terhadap kesediaan pelajar menggunakan bus sekolah dengan menggunakan analisis Crosstab. Berikut adalah tabel hasil analisis persilangan Crosstab:

Tabel 8.

Hasil analisis persilangan Crosstab

\begin{tabular}{cccc}
\hline Variabel & $\begin{array}{c}\text { Nilai } \\
\text { Sig. }\end{array}$ & Keterangan & Keputusan \\
\hline $\begin{array}{c}\text { Kepemilikan } \\
\text { Kendaraan }\end{array}$ & 0.081 & Tolak $\mathrm{H}_{0}$ & Berpengaruh \\
Jenis Kelamin & 0.271 & Terima $\mathrm{H}_{0}$ & $\begin{array}{c}\text { Tidak } \\
\text { Berpengaruh }\end{array}$ \\
$\begin{array}{c}\text { Panjang } \\
\text { Perjalanan } \\
\text { Waktu }\end{array}$ & 0.876 & Terima $\mathrm{H}_{0}$ & $\begin{array}{c}\text { Tidak } \\
\text { Berpengaruh } \\
\text { Tidak }\end{array}$ \\
Keberangkatan & 0.659 & Terima $\mathrm{H}_{0}$ & \begin{tabular}{c} 
Berpengaruh \\
\hline \hline
\end{tabular}
\end{tabular}




\begin{tabular}{|c|c|c|c|}
\hline Variabel & $\begin{array}{l}\text { Nilai } \\
\text { Sig. }\end{array}$ & Keterangan & Keputusan \\
\hline $\begin{array}{c}\text { Waktu } \\
\text { Kepulangan }\end{array}$ & 0.965 & Terima $\mathrm{H}_{0}$ & $\begin{array}{c}\text { Tidak } \\
\text { Berpengaruh }\end{array}$ \\
\hline Waktu Tempuh & 0.634 & Terima $\mathrm{H}_{0}$ & $\begin{array}{c}\text { Tidak } \\
\text { Berpengaruh }\end{array}$ \\
\hline
\end{tabular}

Dari hasil chi-square test dihasilkan nilai sig. dari persilangan karateristik pelajar dan perjalanannya dengan kesediaan menggunakan bus sekolah. Suatu hubungan antara dua variabel tersebut, dapat diketahui dengan dasar hipotesis sebagai berikut:

$\mathrm{H} 0=$ Tidak ada pengaruh variabel kepemilikan kendaraan terhadap kesediaan menggunakan bus sekolah

$\mathrm{H1}=$ Ada pengaruh variabel kepemilikan kendaraan terhadap kesediaan menggunakan bus sekolah

Hasil persilangan menggunakan analisis Crosstab, didapati nilai signifikansi variabel kepemilikan kendaraan dengan kesediaan menggunakan bus adalah 0.081, jenis kelamin dengan kesediaan menggunakan bus sekolah adalah 0.271, panjang perjalanan dengan kesediaan menggunakan bus adalah 0.876 , waktu berangkat dengan kesediaan mengunakan bus adalah 0.659, waktu kepulangan dengan kesediaan menggunakan bus adalah 0.965 , waktu tempuh dengan kesediaan menggunakan bus adalah 0.634 .

Kemudian dari hasil nilai signifikansi tersebut, dasar dalam mengambil keputusan adalah jika nilai sig. hitung $>0.1$, maka HO diterima dan jika nilai sig. hitung < 0.1, maka H0 ditolak. Maka dapat disimpulkan bahwa dari karakteristik pelajar dan perjalanannya menuju sekolah, yang berpengaruh dalam kesediaan menggunakan bus sekolah adalah variabel kepemilikan kendaraan dengan nilai signifikansi 0.081

\section{Uji Koefisien Kontingensi}

Setelah diketahui variabel-variabel yang berpengaruh terhadap kesediaan menggunakan bus sekolah, perlu dilakukan uji koefisien kontingensi. Uji koefisien kontingensi dilakukan untuk mengetahui besaran keterkaitan hubungan antar variabel-variabel yang diuji. Menurut Sugiyono (2007), pedoman untuk memberikan interpretasi koefisien kontingensi adalah sesuai tabel berikut:

Tabel 9.

Kriteria Koefisien Kontingensi

\begin{tabular}{cc}
\hline \hline Nilai & Kriteria \\
\hline $0-0,199$ & Sangat Rendah \\
$0,2-0,399$ & Rendah \\
$0,4-0,599$ & Sedang \\
$0,6-0,799$ & Kuat \\
$0,8-1$ & Sangat Kuat \\
\hline \hline
\end{tabular}

Sumber: Hasil analisis, 2017

Dari tabel kriteria tersebut, diketahui bahwa koefisien kontingensi memiliki rentang nilai yang dimulai dari angka 0 hingga 1. Apabila koefisien semakin mendekati 1, maka hubungan kedua variabel semakin kuat, dan sebaliknya. Berikut merupakan nilai koefisien kontingensi variabel karakteristik pelajar dan perjalanannya:
Tabel 10.

Nilai Koefisien Kontingensi Variabel Karakteristik Pelajar dan Perjalanannya

\begin{tabular}{ccc}
\hline \hline Variabel & $\begin{array}{c}\text { Nilai } \\
\text { Kontingensi }\end{array}$ & Kriteria \\
\hline $\begin{array}{c}\text { Kepemilikan } \\
\text { Kendaraan }\end{array}$ & 0.209 & Rendah
\end{tabular}

\begin{tabular}{ccc} 
Jenis Kelamin & 0.104 & Sangat Rendah \\
$\begin{array}{c}\text { Panjang Perjalanan } \\
\text { Waktu } \\
\text { Keberangkatan }\end{array}$ & 0.165 & Sangat Rendah \\
Waktu Kepulangan & 0.209 & Rendah \\
Waktu Tempuh & 0.194 & Sangat Rendah \\
\hline
\end{tabular}

Sumber: Hasil analisis, 2017

Berdasarkan hasil uji koefisien kontingensi tersebut, maka diketahui bahwa keterkaitan variabel kepemilikan kendaraan dan waktu keberangkatan memiliki kriteria rendah. Variabel jenis kelamin, panjang perjalanan, waktu kepulangan dan waktu tempuh memiliki kriteria sangat rendah.

\section{KESIMPULAN}

Karakteristik pelajar dan perjalanannya menuju sekolah yang signifikan berpengaruh terhadap kesediaan menggunakan bus sekolah adalah tingkat kepemilikan kendaraan, dengan nilai signifikansi sebesar 0.081 dengan nilai koefisien kontingensi 0,209 yang berarti memiliki keterkaitan rendah.

Menurunnya penggunaan bus sekolah dan meningkatnya penggunaan kendaraan pribadi, menyimpulkan bahwa pelajar cenderung memutuskan menggunakan kendaraan pribadi sebagai angkutan menuju sekolah. Semakin tinggi tingkat kepemilikan kendaraan pribadi, akan mempengaruhi pelajar untuk menggunakan kendaraan pribadi sebagai angkutan sekolah. Persaingan moda angkutan tersebut merupakan suatu pilihan yang tidak dapat dipaksakan. Oleh karena itu, perlunya peningkatkan pelayanan angkutan bus sekolah sebagai strategi untuk meningkatkan kesediaan pelajar dalam menggunakan bus sekolah sebagai angkutan menuju sekolah di Kota Surabaya

\section{DAFTAR PUSTAKA}

[1] E.K. Morlok, Pengantar Teknik dan Perencanaan Transportasi. Jakarta: Erlangga, 1984.

[2] Herry Judhi Pratikno, "Analisis Penggunaan Angkutan Penumpang Umum," Universitas Diponegoro, 2006.

[3] Badan Pusat Statistika Kota Surabaya, Surabaya dalam Angka (2016). Surabaya, 2016.

[4] Wijaya dan Dinanti, "Jurnal Studi Evaluasi Pengoperasian Bus Sekolah Gratis di Kota Blitar," 2015.

[5] Dinas Perhubungan Kota Surabaya, Studi permodelan transportasi. 2016.

[6] M. H. Rahman, Syed Masiur and Al-Ahmadi, "Evaluation of Transportation Demand Management (TDM) Strategies and Its Prospect in Saudi Arabia," vol. 4, no. 2, 2010.

[7] erik Ferguson, Travel Demand Management and Public Policy. United State of America: Ashgate, 2000.

[8] erik Ferguson, Travel Demand Management. United State of America: Ashgate, 2000.

[9] E. S. W. Tangkudung, "Bus Sekolah: Tinjauan Layanan dan 
Keselamatan," in The 17th FSTPT International Symposium, 2014.

[10] R. Widyastuti, Hera; Herijanto, Wahju dan Sekartadji, "Rekayasa Infrastruktur Transportasi, Jurnal Studi Demand and Supply Bus Sekolah untuk Siswa Sekolah Menengah Pertama dan Atas di Area Jalan Wijaya Kusuma," 2015.

[11] O. Z. Prayudyanto, Muhammad Nanang dan Tamin, "Mode Shift Travel Demand Management Evaluation From Jakarta's Experience," J. Proc. East. Asia Soc. Transp. Stud., vol. 7, 2009.

[12] D. P. K. Surabaya, "Jadwal Bus Sekolah," e-dishub dinas perhubungan kota surabaya, 2017. [Online]. Available: http://dishub.surabaya.go.id/index.php/post/id/1844. 